Lazaruk T., Fediv O. Assessment of bioelectrical impedance analysis in patients with chronic pancreatitis and chronic obstructive pulmonary disease considering exocrine pancreatic insufficiency. Journal of Education, Health and Sport. 2021;11(1):219-224. eISSN 2391-8306. DOI http://dx.doi.org/10.12775/JEHS.2021.11.1.021

https://apcz.umk.pl/czasopisma/index.php/JEHS/article/view/JEHS.2021.11.1.021

https://zenodo.org/record/4557852

8

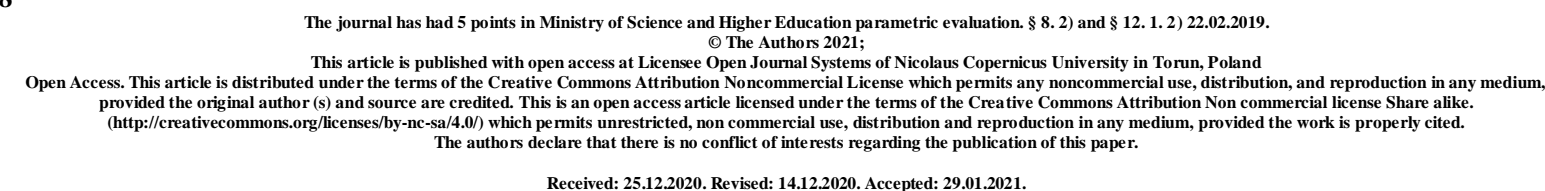

Received: 25.12.2020. Revised: 14.12.2020. Accepted: 29.01.2021.

\title{
ASSESSMENT OF BIOELECTRICAL IMPEDANCE ANALYSIS IN PATIENTS WITH CHRONIC PANCREATITIS AND CHRONIC OBSTRUCTIVE PULMONARY DISEASE CONSIDERING EXOCRINE PANCREATIC INSUFFICIENCY
}

\author{
T. Lazaruk, O. Fediv
}

\section{Bukovinian State Medical University, Chernivtsi, Ukraine}

\begin{abstract}
The article describes and analyzes the results of bioelectrical impedance analysis in patients with chronic pancreatitis and chronic obstructive pulmonary disease considering the level of fecal elastase-1.

The aim of our study was to investigate the features of Bioelectrical impedance analysis in patients with chronic pancreatitis (CP) and chronic obstructive pulmonary disease (COPD) considering the level of fecal elastase-1.

Materials and methods. We examined 84 patients: 30 patients with $\mathrm{CP}$ and 54 patients with comorbid pathology - CP and COPD aged 30-65 years (52.36 \pm 1.83 years). Patients were hospitalized in the gastroenterology department of the Regional Clinical Hospital, Chernivtsy, Ukraine with exacerbation of CP. COPD was in stable or unstable remission. Fecal elastase-1 level was determined by using the Pancreatic Elastase ELISA (BIOSERV Diagnostics). Biometric measurements were performed with a body composition analyzer BC-601 (TANITA, Japan). All examined patients were divided into groups depending on the exocrine pancreatic insufficiency (EPI): severe $(n=9)$, moderate $(n=34)$, mild $(\mathrm{n}=23)$ and normal $(\mathrm{n}=18)$.
\end{abstract}


Results. The group of patients with severe EPI was characterized by weight loss. It can be explained by the appearance of absorption disorders of nutrients (malabsorption and maldigestion syndromes). In the groups of moderate and mild EPI fat and cell mass were significantly lower than normal rate in control group. There is a positive correlation between fecal elastase- 1 and the level of patients' metabolism $(\mathrm{p}<0,05)$.

Conclusions. Bioelectrical impedance analysis (percentage of fat mass, visceral fat level and muscle mass) correlates with the level of fecal elastase-1, which can be used as an additional criteria for the severity of $\mathrm{CP}$ and for the control of the effectiveness of substitution therapy.

Key words: bioelectrical impedance analysis; fecal elastase-1; chronic pancreatitis; chronic obstructive pulmonary disease.

The use of Bioelectrical impedance analysis (BIA) is widespread both in healthy subjects and patients, but suffers from a lack of standardized method and quality control procedures. BIA allows the determination of the fat-free mass (FFM) and total body water (TBW) in subjects without significant fluid and electrolyte abnormalities, when using appropriate population, age or pathology-specific BIA equations and established procedures. Published BIA equations validated against a reference method in a sufficiently large number of subjects are presented and ranked according to the standard error of the estimate [1]. Bioelectrical impedance analysis (BIA) is a non-invasive diagnostic test used for estimating human body composition by measuring the electrical resistance of the different parts of the body. This study makes it possible to obtain reliable estimates of fat, protein and water metabolism, as well as a number of metabolic processes in the body. The main essence of this method is the passage of a weak electric current through the body, which is different in body tissues (muscle, fat, bone, etc.). As a result, a general picture of the percentage of fat and muscle mass in our body is formed [2,3]. It depends on the intensity of the charge passing through different parts of the body. The procedure is completely painless. This study provides an opportunity to obtain reliable estimates of fat, protein and water metabolism, as well as a number of metabolic processes in the body [4].

Why is it so important to determine the percentage of patients body with BIA? Recently, scientists have come to the common idea that it is appropriate to determine not the body mass index (BMI), but the percentage of muscle or fat mass [3, 5]. Therefore, in order to obtain an objective assessment and a clearer picture of the general condition of patients' body, 
it is important to use the method of determining the quantitative composition of the body Bioelectrical impedance analysis.

The aim of the study was to investigate the features of Bioelectrical impedance analysis in patients with chronic pancreatitis (CP) and chronic obstructive pulmonary disease (COPD) considering the level of fecal elastase-1.

Materials and methods. We examined 20 patients with $\mathrm{CP}$ and 40 patients with comorbid pathology - CP and COPD aged 35-65 years (52.36 \pm 1.83 years). Patients were hospitalized in the gastroenterology department of the Regional Clinical Hospital, Chernivtsy, Ukraine with exacerbation of CP. COPD was in stable remission. Respondents were informed about the study and gave their consent. A control group of 20 practically healthy individuals, aged from 35 to 60 years $(50.18 \pm 1.25$ years) was formed.

The diagnosis of CP and the prescriptions were based on the order of the Ministry of Health of Ukraine № 638 (10.09.2014) [6]. The diagnosis of COPD and the prescriptions were based on the order of the Ministry of Health of Ukraine № 555 (27.06.2013) [7]. Standards of diagnosis, treatment and European classifications were taken into account.

Fecal elastase-1 level was examined by using the Pancreatic Elastase ELISA (BIOSERV Diagnostics). The results were evaluated according to generally accepted norms: severe exocrine pancreatic insufficiency (EPI) $<100 \mathrm{mkg}$ of elastase per $1 \mathrm{~g}$ of feces; moderate exocrine pancreatic insufficiency - 100-150 mkg of elastase per $1 \mathrm{~g}$ of feces; mild exocrine pancreatic insufficiency - 150-200 mkg/g; normal exocrine function of the pancreas $>200 \mathrm{mkg} / \mathrm{g}$ of feces.

Biometric measurements were performed on a body composition analyzer BC-601 (TANITA, Japan). The body weight, height, BMI, bone mass, body water percentage, body fat mass, visceral fat level, daily calorie diet, muscle mass, metabolic age were determined

The criterion for inclusion in the study was exocrine pancreatic insufficiency. All examined patients were divided into groups depending on the presence of exocrine pancreatic insufficiency $(E P I)$ : severe $(n=14)$, moderate $(n=21)$, mild $(n=22)$. Only three patients had normal secretion of the pancreas. They were excluded from the study.

Statistical processing of the results was performed using statistical analysis applications "Statistica 10.0" (StatSoft Inc., USA) and "Microsoft Excel 2010" (Microsoft) using parametric and non-parametric methods of analysis.

\section{Results and their discussion}

The level of fecal elastase in patients with mild EPI did not have a significant difference $(\mathrm{p}=0,09)$. In patients with moderate and severe EPI level of fecal elastase was 
significantly below normal rates $(\mathrm{p}<0,05)$. Table 1 shows the average values of fecal elastase levels by groups, as well as the results of the control group. Level of fecal elastase-1 in control group of patients was highly above $200 \mathrm{mkg} / \mathrm{g}(264 \pm 28 \mathrm{mkg} / \mathrm{g})$. This is the normal value according to the level of international standardized indicators.

Table 1. Fecal elastase-1 levels in patients with CP and COPD

\begin{tabular}{|l|c|c|c|c|}
\hline & \multicolumn{3}{|c|}{$\begin{array}{c}\text { Patients with EPI } \\
(\mathrm{n}=66)\end{array}$} & \multirow{2}{*}{$\begin{array}{c}\text { Control group } \\
(\mathrm{n}=20)\end{array}$} \\
\cline { 2 - 5 } & $\begin{array}{c}\text { Severe EPI } \\
(\mathrm{n}=14)\end{array}$ & $\begin{array}{c}\text { Moderate EPI } \\
(\mathrm{n}=21)\end{array}$ & $\begin{array}{c}\text { Mild EPI } \\
(\mathrm{n}=22)\end{array}$ & \\
\hline $\begin{array}{l}\text { Fecal elastase-1, } \\
\text { mkg/g }\end{array}$ & $74,37 \pm 3,12^{*}$ & $108,52 \pm 2,89^{*}$ & $176,13 \pm 2,24$ & $219,32 \pm 2,83$ \\
\hline
\end{tabular}

- between the control group and the examined patients found a statistically significant difference $-\mathrm{p}<0,05$

At the same time, in all groups of the patients Bioelectrical impedance analysis was determined. Analyzing the main indicators of BMI in the group of patients with severe and moderate EPI and COPD, body weight deficiency $(\mathrm{BMI}=17,13 \pm 1,34)$ was detected. This can be explained by the malabsorption and maldigestion syndromes. The presence of concomitant COPD and severe body weight deficiency led to the complicated course of the main disease CP. In patients with CP and COPD with mild EPI BMI was normal. Analyzing the indicators of BIA (Table 2) we discovered, that the fat mass and muscle mass in patients with severe and moderate EPI were significantly lower than in healthy individuals of the control group $(\mathrm{p}<0,05)$.

Table 2. The main indicators of body composition by the Bioelectrical impedance analysis in patients with $\mathrm{CP}$ and COPD

\begin{tabular}{|l|c|c|c|c|}
\hline \multirow{2}{*}{ Indicator } & \multicolumn{3}{|c|}{$\begin{array}{c}\text { Patients with EPI } \\
(\mathrm{n}=66)\end{array}$} & $\begin{array}{c}\text { Control group } \\
(\mathrm{n}=20)\end{array}$ \\
\cline { 2 - 5 } & $\begin{array}{c}\text { Severe EPI } \\
(\mathrm{n}=14)\end{array}$ & $\begin{array}{c}\text { Moderate EPI } \\
(\mathrm{n}=21)\end{array}$ & $\begin{array}{c}\text { Mild EPI } \\
(\mathrm{n}=22)\end{array}$ & $29 \pm 1,23$ \\
\hline Fat mass (FM), \% & $20 \pm 0,15^{*}$ & $23 \pm 0,17^{*}$ & $27 \pm 0,21$ & $34 \pm 0,76$ \\
\hline $\begin{array}{l}\text { Muscle mass } \\
\text { (MM), kg }\end{array}$ & $25 \pm 0,89^{*}$ & $27 \pm 1,02^{*}$ & $29 \pm 0,87^{*}$ & $53 \pm 0,87$ \\
\hline $\begin{array}{l}\text { Total body water } \\
\text { (TBW), \% }\end{array}$ & $48 \pm 1,02$ & $49 \pm 1,02$ & $49 \pm 0,86$ & $3 \pm 0,56$ \\
\hline Visceral fat & $7 \pm 0,35^{*}$ & $7 \pm 0,76^{*}$ & $8 \pm 0,86^{*}$ & $23,37 \pm 1,13$ \\
\hline BMI * - between the control group and the examined patients found a statistically
\end{tabular}
significant difference $-\mathrm{p}<0,05$ 
In patients with severe exocrine insufficiency, the indicators were as follows: muscle mass $-25 \pm 0.89$, fat mass $-20 \pm 0.15$. These indicators differed significantly from the control group ( $\mathrm{p}<0,05)$. In patients with moderate exocrine insufficiency, fat mass indices differed significantly from those in the control group $(\mathrm{p}<0.05)$.

The muscle mass values in groups of the patients with comorbid pathology (CP and COPD) with moderate and mild EPI were significantly lower than in control group $(p<0,05)$. Total body water and percentage of bone mass were within normal limits. A positive correlation between the fecal elastase-1 level and main indicators of the patient's metabolism $(\mathrm{p}<0,05)$ was obtained. A mutually aggravating course of comorbid pathology has also been established.

\section{Conclusions}

1. Patients with chronic pancreatitis and chronic obstructive pulmonary disease with severe exocrine pancreatic insufficiency were characterized by the deficiency of body weight, fat and muscle mass.

2. Patients with chronic pancreatitis and chronic obstructive pulmonary disease with mild exocrine pancreatic insufficiency had decreased levels of BMI and the percentage of muscle and fat mass.

3. Bioelectrical Impedance Analysis indicators (percentage of fat mass, visceral fat level and muscle mass) correlates with the level of fecal elastase-1, which can be used as an additional criteria for the severity of chronic pancreatitis and for the control of the effectiveness of substitution therapy, prognosis and rehabilitation programs.

\section{References}

1. Bellafronte NT, Batistuti MR, Dos Santos NZ, Holland H, Romão EA, G Chiarello P. Estimation of Body Composition and Water Data Depends on the Bioelectrical Impedance Device. J Electr Bioimpedance. 2018 Dec 31;9(1):96-105. doi: 10.2478/joeb2018-0014. PMID: 33584925; PMCID: PMC7852023.

2. Gubergrits, N.B., \& Golubova, O.A. (2014). Bioimpedansometriya u bolnykh s khronicheskym pankreatitom s vneshnesekretornoy nedostatochnostyu podzheludochnoy zhelezy [Bioimpedansometry in patients with chronic pancreatitis with exocrine pancreatic insufficiency]. Eksperymentalnaya i klinicheskaya gastroenterologiya - Experimental and Clinical Gastroenterology, 5 (105), 50 [in Russian]. 
3. Ye. S. Sirchak, S. M. Opalenyk, N. Yu. Kurchak (2019). Features of bioimpedansometry in patients with chronic pancreatitis and atherosclerosis Zdobutku klinichnoi ta eksperymentalnoi mediciny, № 1, 121-124 [in Ukrainian].

4. Stepanov, Yu.M., Boiko, T.Y., Sorochan, O.V., \& Stoikevych, M.V., \& Shkaredna, A.S. (2015). Bioimpedansometriia v otsintsi nutrityvnoho statusu khvorykh na khronichni zapal ni zakhvoriuvannia kyshechnyka [Bioimpedansometry in assessing the nutritional status of patients with chronic inflammatory bowel disease]. Hastroenterolohiia Gastroenterology, 2 (56), 59-66 [in Ukrainian].

5. G.Y. Stupnytska (2013). Bioimpedansometry indicators in patients with chronic obstructive pulmonary disease with accompanying obesity and exercise tolerance. Buk. Med. Herald. - Vol. 17, № 4 (68). - P. 148-153 [in Ukrainian].

6. $\quad$ http://www.moz.gov.ua/ua/portal/dn_20140910_0638.html

7. http://www.moz.gov.ua/ua/portal/dn 20130627 0555.html 